\title{
Thromboangiitis obliterans: A rare case report
}

\author{
Tromboanjiitis obliterans: Nadir bir olgu sunumu
}

\author{
Yusuf Karanc1(i) Cihan Bedel (1) \\ Department of Emergency Medicine, University of Health Sciences, Antalya Training and Research Hospital, Antalya, Turkey
}

\begin{abstract}
Thromboangiitis obliterans (TAO) or Buerger's disease, is a progressive disease with segmental involvement in the small and medium-sized arteries and veins in the lower and upper extremities. It usually affects men less than 40 years old and is associated with tobacco as a predisposing factor. Exclusion of systemic diseases is one of the important diagnostic criteria. Early diagnosis and treatment is important because a majority patients require amputation. In this article, we report a case of a 30-year-old male diagnosed with TAO presented as pain and discoloration in his foot. This case aims to remind emergency physicians of TAO diagnosis in patients who present with pain and discoloration in the foot.

Keywords: Buerger's disease, peripheral vascular diseases, thromboangiitis obliterans.
\end{abstract}

ÖZ

Tromboanjiitis obliterans (TAO) ya da Buerger hastalığı alt ve üst ekstremitelerdeki küçük-orta boy arter ve venlerde segmental tutulum gösteren ilerleyici bir hastalıktır. Genellikle 40 yaşın altındaki erkekleri etkiler ve predispozan faktör olarak tütün kullanımı ile ilişkilidir. Sistemik hastalıkların ekarte edilmesi önemli tanı kriterlerinden biridir. Hastaların büyük bir bölümü amputasyona maruz kaldığından erken tanı ve tedavisi önemlidir. Bu yazıda ayakta ağıı ve renk değişikliği ile başvuran, TAO tanısı konulan 30 yaşında bir erkek olgu sunuldu. Bu olgu, acil hekimleri için ayakta ağrı ve renk değişikliği ile başvuran hastalarda TAO tanısını hatırlatmayı amaçlamaktadır.

Anahtar sözcükler: Buerger hastalığı, periferik damar hastalığı, tromboanjiitis obliterans.

Buerger's disease or thromboangiitis obliterans (TAO) is a thrombotic occlusive, non-atherosclerotic segmental inflammatory disease that most commonly affects small and medium-sized arteries and vein. ${ }^{[1]}$ The pathogenesis of this disease is still generally unknown, but smoking is considered as a trigger factor. Thromboangiitis obliterans typically affects young male with a clinical history of smoking from Asia and Eastern Europe, but the prevalence in women is increasing due to tobacco consumption. $^{[1,2]}$ It is clinically characterized by coldness, intermittent claudication, pain, and distal ischemic ulcers that can develop into necrosis and gangrene, often requiring amputation. ${ }^{[3]}$ Diagnosis and treatment of this condition is difficult, so it requires the exclusion of many other causes and a multidisciplinary approach. In this case, we would like to highlight a case of TAO in a 30-year-old male patient without any medical or traumatic history.

\section{CASE REPORT}

A 30-year-old male presented to the emergency department with complaints of pain and discoloration in his left fifth toes. He stated that he began having pain in his left great toe about one week earlier and noticed some discoloration at the tip of that toe. The patient was admitted to various doctors with increasing

Received: March 29, 2019 Accepted: April 25, 2019 Published online: July 31, 2019

Correspondence: Cihan Bedel, MD. SBÜ Antalya Eğitim ve Araştırma Hastanesi, Acil Tıp Kliniği, 07100 Muratpaşa, Antalya, Turkey. Tel: +90 507-5641254 e-mail: cihanbedel@hotmail.com 
left foot pain for the last two weeks and he stated that treatment with different diagnoses was started. He denied any known trauma or injury, any similar symptoms, fever, chills, chest pain, shortness of breath, recent malaise or history of venous thromboembolism.

The patient had a 10-pack year history of smoking, denied drug abuse (including Cannabis), without any other medical complaints in his past, and no family history of any known illness. On admission to the emergency department, the patient's vital signs were normal and stable. Upper limb peripheral pulses were normal. The patient presented a cyanotic ulcerated lesion involving the two distal thirds of the fifth left toe (Figure 1). Dorsalis pedis and posterior tibial pulses were absent.

Preliminary blood work-up (complete blood count, electrolyte, creatinine, glucose, C-reactive protein level measurements) was within the normal range. Other serological tests for immunological markers and autoantibodies were normal or negative. Hematological evaluation completed later on did not identify any hypercoagulable state. Computed tomography angiography revealed

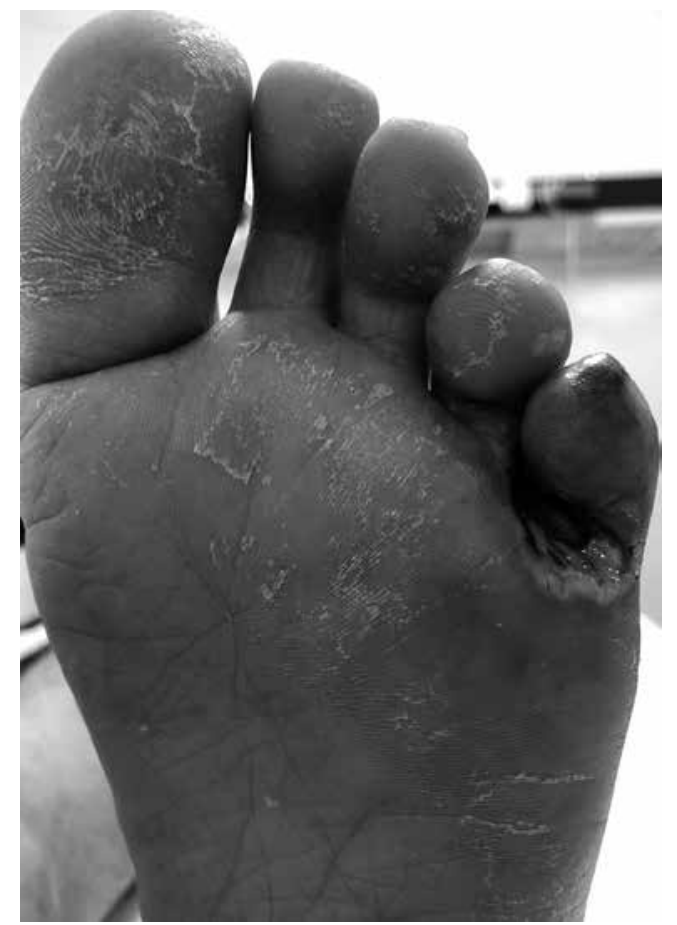

Figure 1. Ulcerated and cyanotic lesion of the second left toe. proximal occlusion of the left posterior tibial and interosseal arteries, with distal circulation by the anterior tibial artery (Figure 2, 3). He was referred to the vascular clinic for ongoing care and medical therapy were given with pentoxifylline infusion, antiplatelet drug (aspirin), low molecular weight heparin (later replaced by oral anticoagulation) and analgesic therapy (morphine, paracetamol and

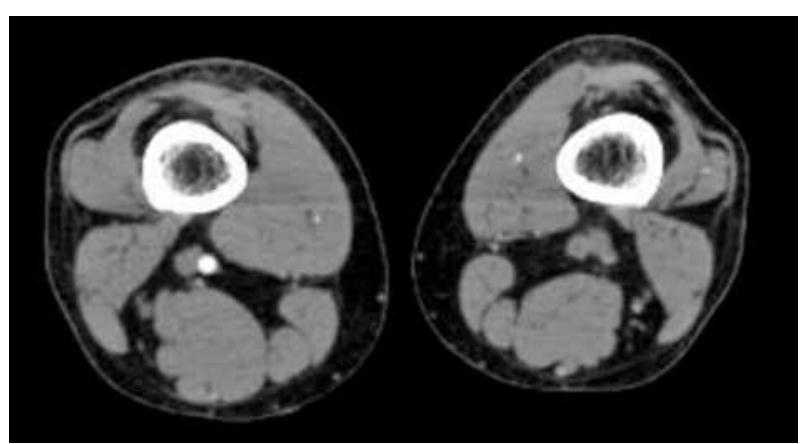

Figure 2. The computed tomography angiography (axial view) revealed proximal occlusion of the left tibial artery.

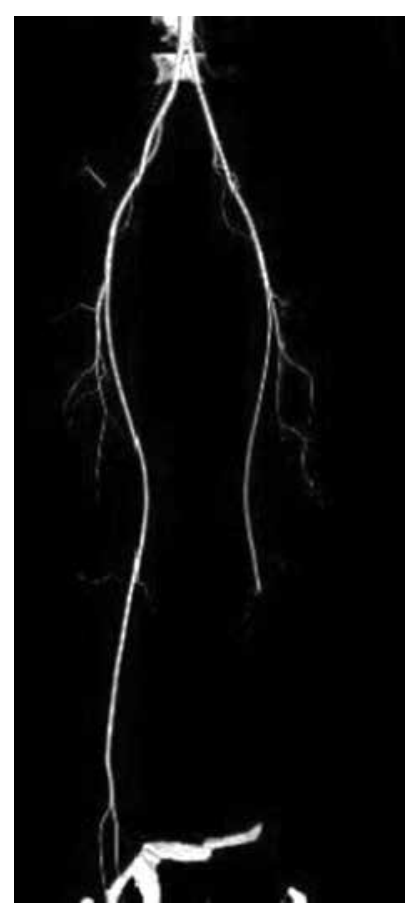

Figure 3. Computed tomography angiography (3D view) revealed occlusion of the distal popliteal artery, tibioperoneal trunk, anterior tibial artery, and posterior tibial artery. 
ibuprofen). The patient was heavily encouraged to stop smoking completely and immediately. A written informed consent was obtained from the patient.

\section{DISCUSSION}

Buerger's disease or TAO nonatherosclerotic vascular disease is a segmental inflammatory disease that typically affects the small- to medium-sized arteries and veins of the upper and lower extremities. Thromboangiitis obliterans is characterized by the absence or minimal presence of atheromas and vasoocclusive phenomenon. ${ }^{[3]}$ Patients with TAO comprise only 4 to $5 \%$ of all those with ischemic peripheral vascular disease. ${ }^{[4]}$ Thromboangiitis obliterans is a different form of systemic vasculitis of unknown etiology (although strongly connected to cigarette smoking) that typically consist of young male smokers, with the initiation symptoms before the age of 40 years. ${ }^{[3]}$

Localization is typically infrapopliteal in the lower extremities and brachial artery in the upper extremities. Ischemic arterial findings include rest pain, intermittent claudication, ischemic ulcers, Raynaud's phenomenon, and gangrene. Physical examination should include palpation of peripheral pulses. ${ }^{[1,5]}$ The conventional diagnosis of TAO is based on these criteria; smoking history, beginning before the age of 50, infrapopliteal arterial occlusive disease, upper extremity involvement or phlebitis migrans and absence of atherosclerotic risk factors except smoking. ${ }^{[6]}$ The diagnosis is based on the correlation between clinical history, physical examination and imaging tests. Systemic autoimmune disease, thrombophilia, diabetes mellitus and proximal embolism should be excluded. Arteriography is the main diagnostic test and biopsy is rarely indicated..$^{[1,7,8]}$ These patients have a high risk of disability and amputation. ${ }^{[8]}$ In a study described a risk of amputation of 11 to 23\%. ${ }^{19]}$ Currently, there is no specific treatment for TAO. The main treatment for TAO patients is to give up smoking or other use of tobacco in any form. ${ }^{[1,3]}$ Medical treatment such as antiplatelets, anticoagulants, thrombolytics, vasodilators pentoxifylline, cilostazol, prostaglandins and endothelin-antagonist can be used to treat a patient with TAO. Surgical procedures can be performed in selected cases. ${ }^{[5]}$

In a conclusion, TAO is a predominantly clinical diagnosis that should be suspected in young male patients who smoke and who present with ischemia of the hands and/or feet. Emergency physicians should keep TAO in mind in patients with pain and discoloration in the toe because early detection and treatment reduce the symptoms of the patients and prevent amputation.

\section{Declaration of conflicting interests}

The authors declared no conflicts of interest with respect to the authorship and/or publication of this article.

\section{Funding}

The authors received no financial support for the research and/or authorship of this article.

\section{REFERENCES}

1. Piazza G, Creager MA. Thromboangiitis obliterans. Circulation 2010;121:1858-61.

2. Caspary L. Erkennen sie diese vaskulitiden? CardioVasc 2012;12:31-6.

3. Olin JW. Thromboangiitis obliterans (Buerger's disease). N Engl J Med 2000;343:864-9.

4. Wadud MA, Taimur SDM, Kabir CS, Roy SP. Buerger $\mathrm{s}$ disease (thromboangiitis obliterans): A diagnostic challenge-a rare case report. BMJ Case Rep 2016;5:37-41.

5. Vijayakumar A, Tiwari R, Kumar Prabhuswamy V. Thromboangiitis obliterans (Buerger's Disease)current practices. Int J Inflam 2013;2013:156905.

6. Shionoya S. Diagnostic criteria of Buerger's disease. Int J Cardiol 1998;66:243-5.

7. Jiménez-Gallo D, Albarrán-Planelles C, ArjonaAguilera C, Blanco-Sánchez G, Rodríguez-Mateos ME, Linares-Barrios M. Treatment of thromboangiitis obliterans (Buerger's disease) with high-potency vasodilators. Dermatol Ther 2015;28:135-9.

8. Ketha SS, Cooper LT. The role of autoimmunity in thromboangiitis obliterans (Buerger's disease). Ann N Y Acad Sci 2013;1285:15-25.

9. Cooper LT, Tse TS, Mikhail MA, McBane RD, Stanson AW, Ballman KV. Long-term survival and amputation risk in thromboangiitis obliterans (Buerger's disease). J Am Coll Cardiol 2004;44:2410-1. 